\title{
Pathological Traits and Adaptability as Predictors of Engagement, Job Satisfaction, Burnout And Workaholism
}

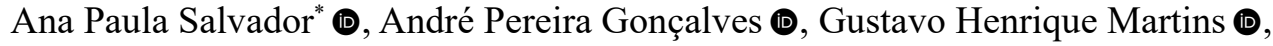 \\ \& Lucas de Francisco Carvalho (1) \\ Universidade São Francisco, Campinas, São Paulo, Brazil
}

\begin{abstract}
This study aimed to test the predictive capacity of pathological traits of personality and career adaptability on four constructs that compose the well-being at work: work engagement, job satisfaction, burnout, and workaholism. A total of 204 Brazilian working adults $(M$ age $=34.02, S D=10.39)$ participated in the study, which responded to scales measuring pathological traits, career adaptability resources, and well-being components at work. Our findings indicate that pathological traits are, in general, negatively related to job satisfaction and work engagement and positively associated with burnout and workaholism. After the insertion of career adaptability, there was an increase in most of the models' explanation. The contribution of adaptability was significant only for job satisfaction prediction.
\end{abstract}

KEYWORDS: personality disorder; organizational psychology; vocational and career guidance; well-being.

\section{Traços Patológicos e Adaptabilidade como Preditores do Engajamento}

\begin{abstract}
RESUMO - Este estudo teve como objetivo testar a capacidade preditiva de traços patológicos da personalidade e adaptabilidade de carreira sobre quatro construtos que compõem o bem-estar no trabalho: engajamento no trabalho, satisfação no trabalho, burnout e workaholism. Participaram 204 adultos brasileiros trabalhadores $(\mathrm{M}$ idade $=34,02 ; \mathrm{DP}=10,39)$ que responderam instrumentos que mensuram traços patológicos, recursos de adaptabilidade de carreira e componentes do bemestar no trabalho. Nossos achados indicaram que os traços patológicos estão, de modo geral, relacionados negativamente com satisfação no trabalho e engajamento no trabalho e positivamente com burnout e workaholism. Após a inserção da adaptabilidade de carreira houve aumento da explicação na maioria dos modelos, sendo que a contribuição única de adaptabilidade foi significativa apenas para predição de satisfação no trabalho.
\end{abstract}

PALAVRAS-CHAVE: personalidade patológica; psicologia organizacional; orientação profissional e de carreira; bem-estar.

Workplace well-being has been a concern of companies of different segments due to its influence on the quality of services provided, employees' productivity, and mental health (Bendassolli, 2016; Couto \& Paschoal, 2017; Wright \& Cropanzano, 2000).

Salanova et al. (2014) developed a taxonomic model for well-being at work. The model consists of a circle divided by two axes. The horizontal axis is related to the intensity of pleasure, and the vertical one is related to the energy given off by the subject carrying out the activities. The authors suggest a model with four fundamental constructs for well-being at work: work engagement, job satisfaction, burnout, and workaholic. These constructs are allocated in the model as follows: work engagement and job satisfaction (positive pole), and burnout and workaholic (negative pole). Our scope was to investigate the predictive capacity of pathological personality traits and career adaptability factors on the components of well-being at work. The following paragraphs present the components of well-being at work and the previously observed associations of these components with pathological traits and career adaptability.

Work engagement is associated with positive workrelated behavior, where high energy is given off to carry out activities resulting in high levels of dedication and focus on

\footnotetext{
*E-mail: salvador.anapaula@outlook.com

- Submetido: 03/07/2019; Aceito: 12/11/2020.
} 
work (Schaufeli, \& Bakker, 2010). People with high levels of work engagement have more energy and enthusiasm in carrying out work activities (Bakker \& Albrecht, 2018), leading to a better performance of employees (Alessandri et al., 2015). Studies also indicate that work engagement is associated with better workers' well-being in organizations (Schaufeli, 2018; Shimazu et al., 2015).

Job satisfaction can be thought of as the level at which an employee is satisfied with the job. In other words, it shows how much the individual is satisfied with elements of daily work, such as the type of activity performed, the relationship with colleagues, with the bosses, with the expectations of the work, and remuneration for the activity performed (Kim et al., 2005; Mueller \& McCloskey, 1990). It refers to the individual's feeling that his work-related needs are being met (Evans, 2001). Studies indicate that job satisfaction is positively related to productivity or performance (Folami et al., 2014; Judge et al., 2000; Platis et al., 2015), and well-being at work (Felstead et al., 2015).

At the opposite pole, burnout consists of a prolonged response to chronic emotional and interpersonal stressors related to the work environment (Salanova et al., 2005; Schaufeli \& Taris, 2005). The low expectation of achieving specific goals at work (enthusiasm towards job), high physical and emotional exhaustion generated by work activity (psychological exhaustion), and high negative attitudes of indifference and cynicism towards people in the work environment (indolence) describe burnout. In addition to these characteristics, burnout can be characterized by the feeling of guilt experienced by individuals at work, especially about interpersonal relationships (Gil-Monte et al., 2010). Burnout has been negatively related to well-being at work (Hall et al., 2016; Rothmann, 2008).

According to the meta-analysis conducted by Clark et al. (2016), there is no agreement in literature regarding the definition of workaholism (and workaholic). Workaholism can be understood as an addiction ( $\mathrm{Ng}$ et al., 2007; Porter, 2006; Robinson, 2000), a pattern of behavior (Scottl et al., 1997), or as a syndrome (Aziz \& Zickar, 2006). The most used assessment scales are based on the concept that workaholism is an addiction to work, namely, Workaholism Battery (Spence \& Robbins, 1992), the Work Addiction Risk Test (WART; Robinson, 1999), and the Dutch Workaholism Scale (DUWAS; Schaufeli et al., 2009).

Our study adopted the following definition for workaholism: the addiction to work that implies negative results for the worker in different areas of life as interpersonal, individual, and in the organization. People with high levels of workaholism are overly concerned with work, failing to perform leisure activities, not worrying about relationships or their health (Andreassen \& Pallesen, 2016). A workaholic worker may have negatively affected performance and poor work-related well-being (Salanova et al., 2014; Shimazu \& Schaufeli, 2009).

Previous studies have investigated relationships between work engagement, job satisfaction, burnout, and workaholism with healthy and pathological personality traits (Andreassen et al., 2016; Carvalho et al., 2019; Mróz \& Kaleta, 2016; Zecca et al, 2015) and career adaptability (Rudolph et al., 2017; Rudolph, Lavigne, \& Zacher, 2017). Evidence on pathological traits indicates an inverse (or negative) relationship with work engagement (Carvalho et al., 2019; Zecca et al., 2015). Pathological personality traits are negatively related to job satisfaction and positively to burnout (Bianchi et al., 2018; Carvalho et al., 2019; Wille et al., 2013), in addition to being positively related to workaholism (Andreassen et al., 2016; Jackson et al., 2016).

Specifically, regarding career adaptability, high levels in this construct have been positively related to work engagement, and job satisfaction. It is also negatively associated with burnout (Rudolph et al., 2017; Rudolph, Lavigne, \& Zacher, 2017). This means that the more resources of career adaptability, the more the worker is satisfied and engaged, and the lower the burnout levels. We did not find studies investigating the relationship between career adaptability and workaholism in which the latter was considered an addiction to work.

This study aimed to test the predictive ability of pathological personality traits and career adaptability on work engagement, job satisfaction, burnout, and workaholism in Brazilian workers. Besides, we sought to verify whether adding career adaptability as a predictor would increase the predictive model of pathological personality traits and well-being components at work. In order to achieve the objectives of this study, factors from the Dimensional Clinical Personality Inventory 2 (IDCP-2; Carvalho \& Primi, in press) were used to measure pathological personality traits and the dimensions of the Career Adapt-Abilities Scale + Cooperation scale (CAAS $+\mathrm{C}$; Ambiel et al., in press) to measure career adaptability resources. We developed five hypotheses, as follows.

H1) The IDCP-2 Compulsion for Work factor, indicated in literature as a characteristic of workaholism (Andreassen \& Pallesen, 2016), in addition to the Concern, Control, Curiosity, Confidence, and Cooperation dimensions of $\mathrm{CAAS}+\mathrm{C}$, representing the resources of career adaptability, should be a positive predictor of work engagement and the Impulsivity, Self-depreciation, Emotional Apathy, and Hopelessness factors of the IDCP-2 negative predictors of work engagement (Bakker \& Albrecht, 2018; Bakker et al., 2014; Rudolph, Lavigne, \& Zacher, 2017; Schaufeli, \& Bakker, 2010; Torp et al., 2012; Zecca et al., 2015).

H2) the Concern, Control, Curiosity, Confidence, and Cooperation dimensions of $\mathrm{CAAS}+\mathrm{C}$, representing the resources of career adaptability, should be positive predictors of job satisfaction, and Self-devaluation, Emotional Apathy, Despair, and Anxious Concern factors of IDCP-2, which represent pathological traits, negative predictors of it (Bradley, \& Roberts, 2004; Judge et al., 2000; NewburyBirch \& Kamali, 2001; Rudolph et al., 2017; Rudolph, Lavigne, \& Zacher, 2017).

H3) Self-devaluation, Emotional Apathy, Vulnerability, Anxious Concern, Hopelessness, Antagonism, Impulsivity, 
and Routine Need factors of IDCP-2, representing pathological traits, should be positive predictors of burnout, and the Concern, Control, Curiosity, Confidence, and Cooperation dimensions of CAAS $+\mathrm{C}$, representing career adaptability resources, negative predictors of it (Armon et al., 2012; Carvalho et al., 2014; Dahlin \& Runeson, 2007; Hakanen et al., 2008; Maslach \& Leiter, 2016; Muscatello et al., 2006; Rudolph et al., 2017; Rudolph, Lavigne, \& Zacher, 2017; Winstanley \& Whittington, 2002).

H4) Concern with Details, Compulsion for Work, Impulsivity and Need for Routine factors of the IDCP2 , representing pathological traits, should be positive predictors of workaholism (Bartczak, \& Ogińska-Bulik, 2012; Carvalho et al., 2014; Clark et al., 2016; Sharma et al., 2013; Stoeber et al., 2013).

H5) Predictive models composed by IDCP-2 factors, representing pathological traits, as predictors, and work engagement, job satisfaction, burnout, and workaholism as predicted variables, should have an increment in the variance explained when Concern, Control, Curiosity, Confidence, and Cooperation dimensions of CAAS $+\mathrm{C}$ were added to the model (Rudolph et al., 2017; Rudolph, Lavigne, \& Zacher, 2017).

\section{METHODS}

\section{Participants}

The sample consisted of 204 working adults, aged 18 to 67 years $(M=34.02 ; S D=10.39)$, the majority of females $(59.8 \%)$, and residing in the Southeast region of Brazil (84.8\%). Most of the participants declared to have a postgraduate degree $(49.5 \%)$, followed by a graduate degree (27\%). Besides, most reported having a formal job $(35.3 \%)$ or being self-employed (22.5\%). Regarding mental health indicators, $53.5 \%$ reported having already undergone psychotherapy, $15.2 \%$ psychiatric treatment, and about $8 \%$ reported having a psychiatric diagnosis.

\section{Instruments}

Dimensional Clinical Personality Inventory 2 - IDCP-2; (Carvalho \& Primi, in press). The IDCP-2 is a self-report scale composed of 206 items to evaluate pathological traits. The higher the score achieved on the factors, the greater the chances of pathological functioning. The answer key is given on a four-point Likert scale, ranging from " 1 - nothing to do with me" to "4 - everything to do with me". For this study, we selected 12 factors (53 items) that would theoretically be related to well-being components at work. The factors are as follows: Self-devaluation, Antagonism, Emotional Apathy, Impulsivity, Vulnerability, Anxious Concern, Hopelessness, Need for Routine, and Compulsion for Work. The internal consistency reliability of this study's factors was considered satisfactory, with alphas ranging from 0.74 (Compulsion for Work) to 0.89 (Self-devaluation).

Career Adapt-Abilities Scale + Cooperation scaleCAAS $+\mathrm{C}$ (Ambiel et al., in press; Audibert \& Teixeira, 2015). The CAAS $+\mathrm{C}$ evaluates career adaptability through 30 items that are equally divided into five dimensions, namely Concern, Control, Curiosity, Confidence, and Cooperation. The answer key is given on a five-point Likert scale that ranges from " 1 - I developed little or nothing" to "5 - I developed extremely well". The internal consistency reliability for this study's dimensions was satisfactory, with alphas ranging from 0.86 (Control) to 0.92 (Concern and Confidence).
Work Satisfaction Scale - Reduced - EST-R (Siqueira, 2008). The EST-R is composed of 15 items evaluating worker satisfaction with the work. The items are distributed in five factors: Satisfaction with Colleagues, Satisfaction with Salary, Satisfaction with Management, Satisfaction with the Nature of Work, and Satisfaction with Promotions. The answer key is given on a seven-point Likert scale, ranging from " 1 - totally dissatisfied" to "7 - totally satisfied". The internal consistency reliability of this study's factors were all satisfactory, with alphas ranging from 0.84 (Satisfaction with the Nature of Work) to 0.96 (Satisfaction with Salary).

Utrecht Work Engagement Scale - UWES-9 (Ferreira et al., 2016). The UWES-9 evaluates work engagement through nine items, composing a single factor. The answer key is given on a seven-point Likert scale ranging from " 0 - never" to " 6 - always". The internal consistency reliability of the UWES-9 in this study was considered satisfactory, with an alpha of 0.95 .

Spanish Burnout Inventory - SBI (Gil-Monte et al., 2010). The SBI evaluates the level of burnout of workers in different occupations. It consists of 20 items distributed in four factors: Enthusiasm towards the job, psychological exhaustion, Indolence, and Guilt. The answer key is given on a five-point Likert scale ranging from " 0 - never" to " 4 - Very often: every day". The internal consistency reliability of the SBI, in this study, was considered satisfactory, with alphas ranging from 0.84 (Guilt) to 0.90 (Enthusiasm towards job).

Dutch Work Addiction Scale 10 - DUWAS-10 (Carlotto \& Del Líbano, 2010). The DUWAS-10 evaluates workaholism through 10 items that are equally divided into two factors: Working Excessively and Working Compulsively. Previous studies report the possibility of evaluating workaholism through a single factor structure due to the strong correlation observed between the two factors of the DUWAS-10 (Carlotto \& Del Líbano, 2010; Vazquez et al., 2018). In our study, a .99 correlation was observed between the two factors. Therefore, we adopted the unifactor structure for the scale. The answer key is given on a 4-points Likert-type scale, being "1 - never" and "4 - every day". This study's internal consistency reliability was considered satisfactory and equal to 0.85 (alpha). 


\section{Procedure}

The research was approved by the Research Ethics Committee (CAAE: 84826118.0.0000.5514). Data collection was online through the Google Forms administration. The invitations were sent on online social networks to potential participants, informing them that only workers $\geq 18$ years old and employed at the time of the survey could participate in the research. The average response time to the instruments was about 35 minutes.

\section{Data analysis}

We conducted the analyzes using the software SPSS 25 and MPlus 7. Initially, descriptive analyzes were performed to characterize the sample. Then we tried to predict the dependent variables work engagement, job satisfaction, burnout, and workaholism using Structural Equation Modeling (SEM). For each dependent variable, we performed two analyzes. First, only the pathological traits (Self-devaluation, Antagonism, Emotional Apathy, Impulsivity, Vulnerability, Anxious Concern, Hopelessness, Need for Routine, Compulsion for Work factors) were included. Second, career adaptability dimensions (Concern, Control, Curiosity, Confidence, and Cooperation) were also included as predictor variables. The estimation method used was the Weighted Least Square Mean and Variance (WLSMV), which uses a polychoric correlation matrix, and the rotation was oblique (Geomin). The model fit was verified employing the following fit indices: chi-square and degrees of freedom ratio $\left(X^{2} / d f<2\right)$, Confirmatory Fit Index (CFI $>.90)$, Tucker-Lewis Index (TLI>. 90), and Root Mean Square Error of Approximation (RMSEA; <.05) (Hu $\&$ Bentler, 1999).

\section{RESULTS}

We tested two predictive models for each dependent variable (work engagement, job satisfaction, burnout, and workaholism). The first model was composed exclusively of the IDCP-2 factors that represent pathological traits as predictor variables. In the second model, in addition to the IDCP-2 factors, we also included the career adaptability dimensions as predictor variables. The values of the two tested models are reported in the figures, with the values between the parentheses referring to the first tested model (IDCP-2) and the values outside the parentheses referring to the second tested model (IDCP-2 and CAAS+C). It is noteworthy that tested models had satisfactory fit indexes, and the factorial loadings of the items were above 0.30 . Figure 1 presents the predictive model for work engagement.

Pathological traits were able to predict $31 \%$ of work engagement. When the dimensions of career adaptability were added, the model explained $43 \%$ of work engagement. The model composed of pathological traits and career adaptability explained more work engagement compared to the model formed only by pathological traits. Selfdevaluation was a significant negative predictor, and Impulsivity, Hopelessness, and Compulsion for work were positive predictors. The Self-devaluation factor was no longer a significant predictor when the dimensions of career adaptability were inserted. The dimensions of career adaptability were not significant predictors of work engagement. Figure 2 presents the predictive model of job satisfaction.

In Figure 2, the model composed of pathological traits and career adaptability better explained the five factors of job satisfaction. The predictors explained $53 \%$ of the variance of Satisfaction with colleagues factor, being Emotional Apathy, Anxious Concern and Concern significant and negative predictors, and Hopelessness and Cooperation significant positive predictors. Satisfaction with salary had $27 \%$ of the variance explained, with Anxious Concern as a significant negative predictor and Concern as a significant positive predictor. Satisfaction with leadership had $40 \%$ of the variance explained by the variables, with Anxious Concern and Concern being significant negative predictors, and Hopelessness and Confidence, positive predictors. Satisfaction with the nature of the work had $42 \%$ of its variance explained by the predictor variables, with a significant and negative contribution of Control, and significant positive contribution of Impulsivity and Curiosity. Finally, 34\% of Satisfaction with promotion was explained, with Anxious Concern being a significant negative predictor and Impulsivity a significant positive predictor. Figure 3 shows the predictive model of burnout.

The complete model (Figure 3) explained the four burnout factors better than the model without all the predictors. Enthusiasm towards the job had $33 \%$ of its variance explained by the variables tested. However, only Emotional Apathy was a significant negative predictor, and Compulsion for Work was a significant positive predictor. Psychological exhaustion had $32 \%$ of the variance explained, with only Self-Devaluation factor being a significant positive predictor. Thirty-four percent of Indolence was explained, with Antagonism and Need for Routine factors being significant positive predictors. Blame was $39 \%$ explained by the variables, but only Impulsivity and Need for Routine were significant positive predictors. No dimension of career adaptability was significant predictor of burnout factors. Figure 4 describes workaholism's predictive model.

The workaholism variable had $62 \%$ of the variance explained by the pathological traits (Figure 4). When we entered the career adaptability dimensions as predictor variables, explained variance dropped to $42 \%$. The first 


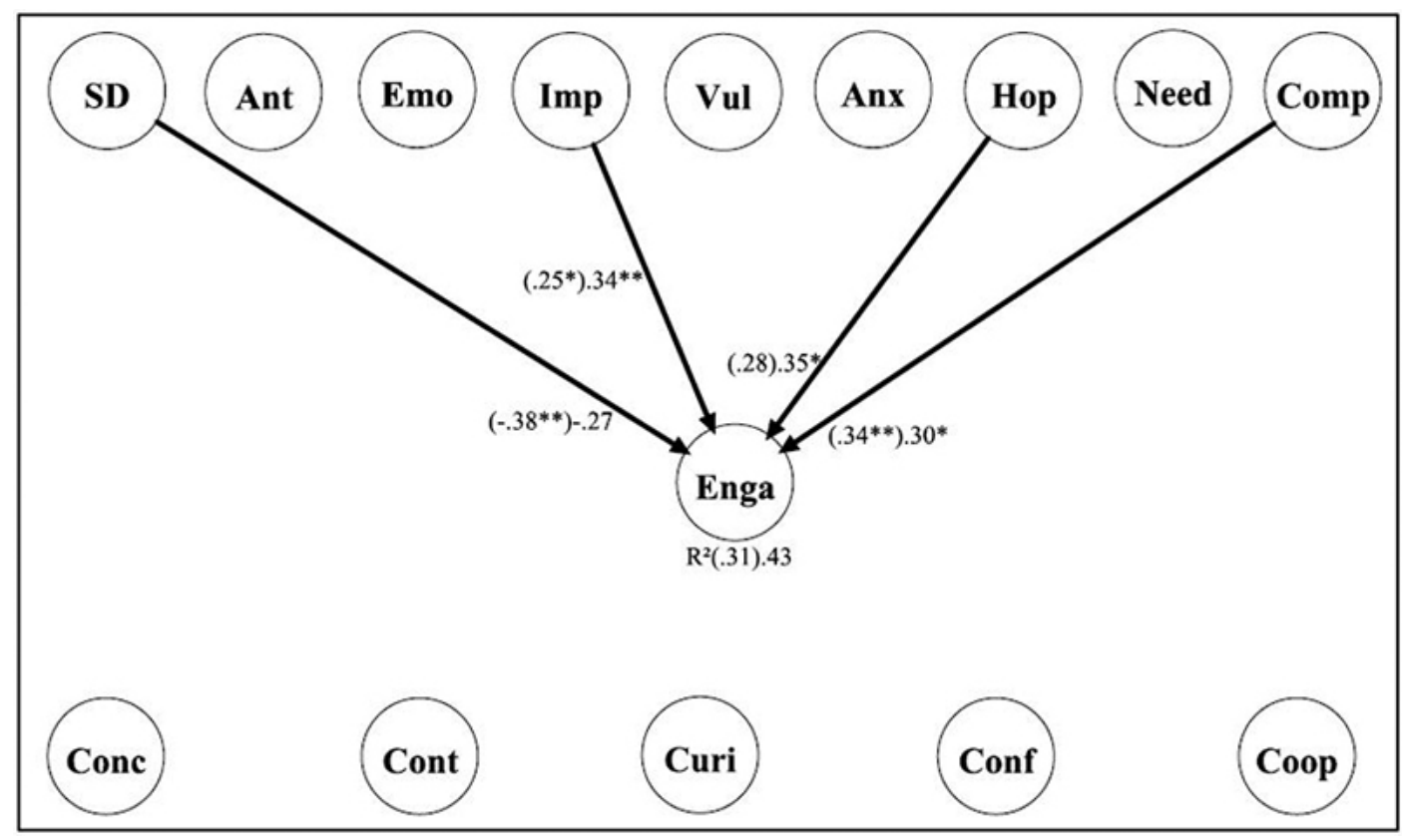

Figure 1. Predictive model of pathological traits and career adaptability on work engagement

Note. Items representing the model were removed from the presentation of results. The figure shows the two predictive models tested, the first is formed only by pathological personality traits as predictor variables and the second is presenting the dimensions of career adaptability added. Values from the first model are in parentheses. Only the values of the variables that were significant predictors were presented $(p<0.05)$; Fit indices of the models: $\left(X^{2} / d f\right.$ $=1.34 ; \mathrm{CFI}=0.97 ; \mathrm{TLI}=0.97 ; \mathrm{RMSEA}=0.04) X^{2} / d f=1.21 ; \mathrm{CFI}=0.97 ; \mathrm{TLI}=0.97 ; \mathrm{RMSEA}=0.03 ; \mathrm{SD}=\mathrm{Self}-$ devaluation; Ant $=$ Antagonism; Emo = Emotional Apathy; Imp = Impulsivity; Vul = Vulnerability; Anx = Anxious worry; Hop = Hopelessness; Need $=$ Routine Need; Comp = Compulsion to work Engage $=$ Engagement Conc $=$ Concern; Cont $=$ Control; Curi $=$ Curiosity; Conf $=$ Confidence Coop $=$ Cooperation .

$* p<0.05 ; * * p<0.01$

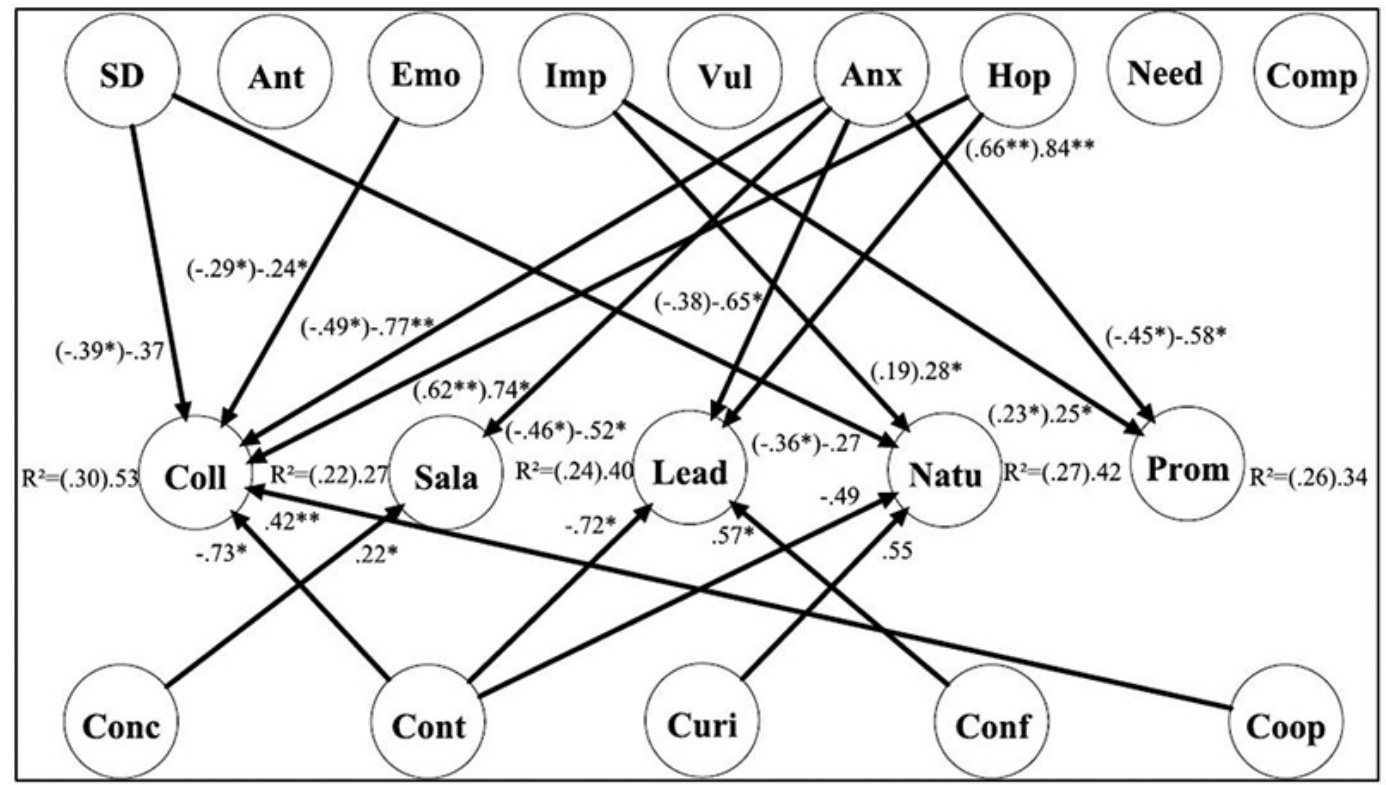

Figure 2. Predictive model of pathological traits and career adaptability on job satisfaction

Note. Items representing the model were removed from the presentation of results. The figure shows the two predictive models tested, the first is formed only by pathological personality traits as predictor variables and the second is presenting the dimensions of career adaptability added. Values from the first model are between parentheses. Only the values of the variables that were significant predictors were presented $(p<0.05)$. Fit indices of the models: $\left(X^{2} / d f\right.$ $=1.24 ; \mathrm{CFI}=0.97 ; \mathrm{TLI}=0.97 ; \mathrm{RMSEA}=0.03) X^{2} / d f=1.18 ; \mathrm{CFI}=0.97 ; \mathrm{TLI}=0.97 ; \mathrm{RMSEA}=0.03 ; \mathrm{SD}=$ Self-devaluation; Ant $=$ Antagonism; Emo $=$ Emotional Apathy; Imp = Impulsivity; Vul = Vulnerability; Anx = Anxious worry; Hop = Hopelessness; Need = Routine Need; Comp = Compulsion to work; Coll = Satisfaction with colleagues; Sala = Satisfaction with salary; Lead = Satisfaction with the boss; Natu = Satisfaction with the nature of the work; Prom $=$ Satisfaction with promotion; Conc = Concern; Cont $=$ Control; Curi $=$ Curiosity; Conf $=$ Confidence; Coop $=$ Cooperation . ${ }^{*} p<0.05 ; * * p<0.01$ 
model is considered to be the best model to explain workaholism. Antagonism and Need for Routine factors were significant negative predictors, and Compulsion for
Work was the significant and positive predictor. None of the dimensions of career adaptability were significant predictors of workaholism.

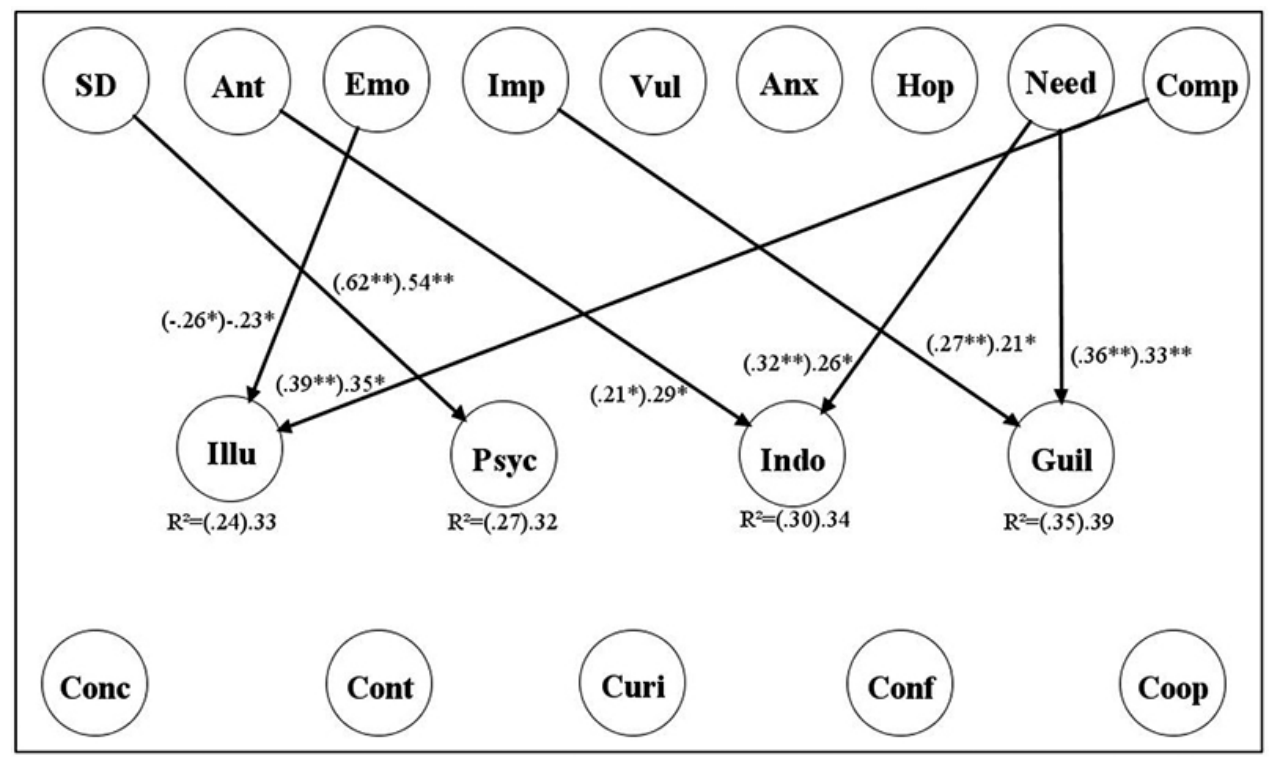

Figure 3. Predictive model of pathological traits and career adaptability on burnout

Note. Items representing the model were removed from the presentation of results. In the figure, the two predictive models tested are represented, the first formed only by pathological personality traits as predictor variables and in the second the dimensions of career adaptability were added. Values from the first model are between parentheses. Only the values of the variables that were significant predictors were presented $(p<0.05)$. Fit indices of the models: $\left(X^{2} / d f=1.23 ; \mathrm{CFI}=0.95 ; \mathrm{TLI}=0.95 ; \mathrm{RMSEA}=0.03\right) X^{2} / d f=1.17$; CFI $=0.96 ; \mathrm{TLI}=0.96 ; \mathrm{RMSEA}=0.03$; $\mathrm{SD}=\mathrm{Self}$-devaluation; Ant = Antagonism; Emo = Emotional Apathy; Imp = Impulsivity; Vul = Vulnerability; Anx = Anxious worry; Hop = Hopelessness; Need = Routine Need; Comp = Compulsion to work; Illu = Illusion for work; Psyc $=$ Psychic wear; Indo = Indolence; Guil = Guilt; Conc $=$ Concern; Cont $=$ Control; Curi = Curiosity; Conf $=$ Confidence; Coop $=$ Cooperation .

$* p<0.05 ; * p<0.01$

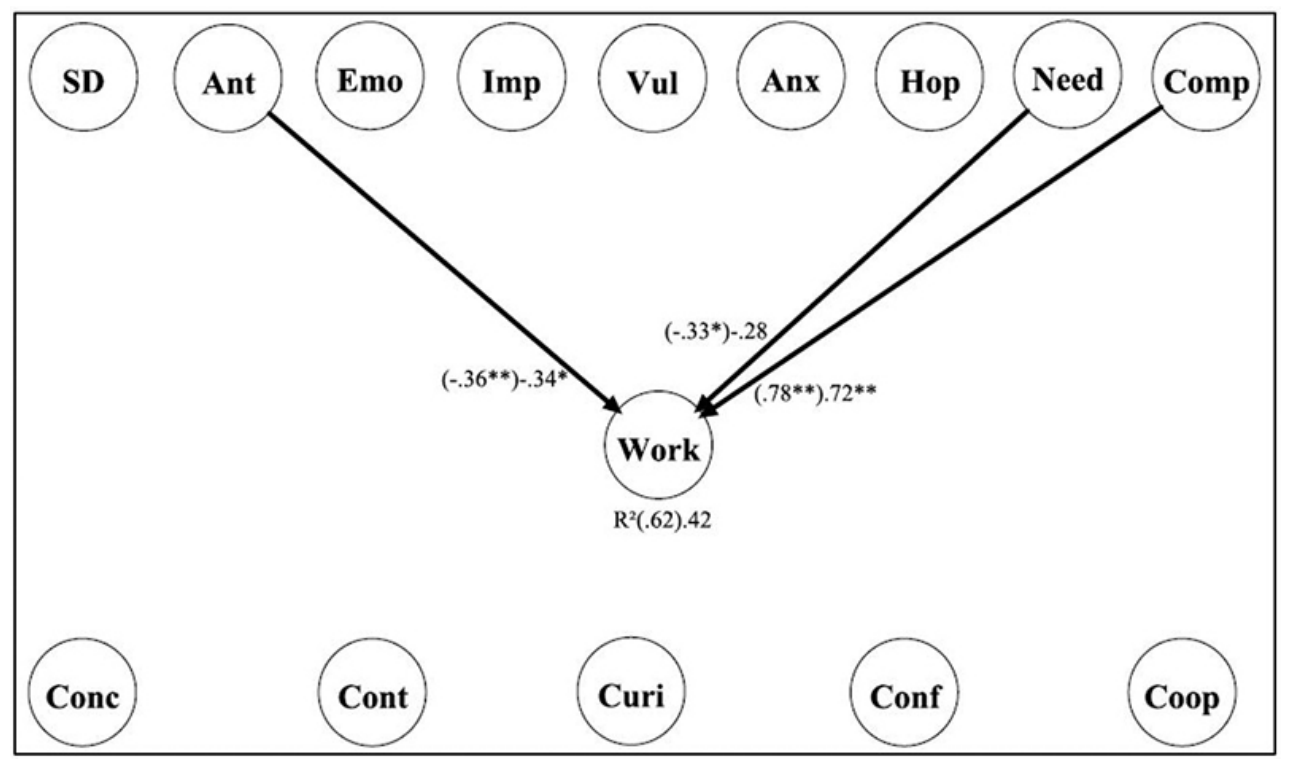

Figure 4. Predictive model of pathological traits and career adaptability on workaholism

Note. Items representing the model were removed from the presentation of results. In the figure, the two predictive models tested are represented, the first formed only by pathological personality traits as predictor variables and in the second the dimensions of career adaptability were added. Values from the first model are between parentheses. Only the values of the variables that were significant predictors were presented $(p<0.05)$. Fit indices of the models: $\left(X^{2} / d f=1.32 ; \mathrm{CFI}=0.95 ; \mathrm{TLI}=0.94 ; \mathrm{RMSEA}=0.04\right) X^{2} / d f=1.24 ; \mathrm{CFI}=0.95 ; \mathrm{TLI}=0.95 ; \mathrm{RMSEA}=0.03$; $\mathrm{SD}=\mathrm{Self}-\mathrm{devaluation}$; Ant $=$ Antagonism $;$ Emo = Emotional Apathy Imp = Impulsivity; Vul = Vulnerability; Anx = Anxious worry; Hop = Hopelessness; Need = Routine Need; Comp $=$ Compulsion to work; Work $=$ Workaholism; Conc $=$ Concern; Cont $=$ Control; Curi $=$ Curiosity Conf $=$ Confidence; Coop $=$ Cooperation . $* p<0.05 ; * * p<0.01$ 


\section{DISCUSSION}

This study aimed to test the predictive ability of pathological traits and career adaptability on work engagement, job satisfaction, burnout, and workaholism in Brazilian workers. Our hypotheses were partially corroborated: H1) the pathological traits were better predictors of work engagement, while the resources of career adaptability were not significant; H2) both pathological traits and career adaptability resources were predictors of job satisfaction; H3) and H4) pathological traits were better predictors of burnout and workaholism, while career adaptability resources were not significant; H5) career adaptability resources increased the explained variance when inserted in the model with pathological traits, except in the explanation of workaholism. The findings are discussed in detail in the following paragraphs.

In the tested model (H1), Impulsivity, Hopelessness, and Compulsion at Work factors were positive predictors of work engagement, while Self-devaluation factor was a negative predictor. Individuals who are reckless and make quick decisions without considering the possibilities (Impulsivity) and believe that the future will not be promising (Hopelessness) (Carvalho \& Primi, in press) obtained higher levels of work engagement. This finding is opposed to this study's hypothesis and to what is reported in literature (Torp et al., 2012; Zecca et al., 2015). Although not expected, these results may be understood based on the frequency of emission of behaviors, i.e., more impulsive people may tend to emit more behaviors as they are less thoughtful. The same can happen with more engaged people, as they are more engaged with the tasks. Future research should seek to test this explanatory possibility. Regarding the Despair factor, it is believed that the positive relationship observed is due to the fact that individuals who face their future with uncertainty seek to engage in their work activities to increase their chances of professional success in the future.

Compulsion for Work factor refers to excessive focus on work (Carvalho et al., 2014; Carvalho \& Primi, 2014). The positive relationship of this factor with work engagement suggests that the more an employee directs his focus to the work activity, the more engaged the individual is in carrying out the task, confirming our hypothesis and literature (Schaufeli, \& Bakker, 2010). Self-devaluation factor is related to low self-esteem to others and the feeling of guilt (Carvalho \& Pianowski, 2015). This factor was negatively related to work engagement, which is similar to the findings of Torp et al. (2012) and confirms our hypothesis.

The dimensions of career adaptability were not able to significantly predict work engagement. These findings contradict what was observed in the meta-analysis conducted by Rudolph, Lavigne, and Zacher (2017). The hypothesis for the divergent results is that pathological traits are better predictors than career adaptability. Because of that, in a model in which there is an interaction between independent variables, pathological traits suppressed the contributions of career adaptability dimensions. This hypothesis must be investigated in future studies.

In the model to predict job satisfaction (H2), Emotional Apathy and Anxious Concern IDCP-2 factors were negative predictors, confirming previous findings (Bradley \& Roberts, 2004; Newbury-Birch \& Kamali, 2001), as well as Control dimension of CAAS $+\mathrm{C}$. Hopelessness and Impulsivity factors and the dimensions Concern, Curiosity, Confidence, and Cooperation were positive predictors and confirmed previous evidence (Bradley \& Roberts, 2004; Rudolph et al., 2017).

Another model (H3) tested the capacity of pathological traits and career adaptability resources to predict burnout. Compulsion for Work, Self-devaluation, Antagonism, Need for Routine, and Impulsivity IDCP-2 factors were positive predictors. These findings indicate that individuals who have an excessive focus on work, interpersonal rigidity, feelings of incapacity and guilt, aggressive conduct, impulsivity, and difficulties in dealing with changes in daily life tend to have more burnout issues, which is in accordance with previous studies (Dahlin \& Runeson, 2007; Hakanen et al., 2008 \& Muscatello et al., 2006). Emotional Apathy factor was a negative predictor of burnout, although we hypothesized this factor as a positive predictor. This finding can be explained by the fact that Enthusiasm towards the job factor refers to positive characteristics, for example, a source of personal and professional fulfillment. Thus, individuals who have expectations of reaching their work goals tend to have less burnout issues, which is in line with literature (Hakanen et al., 2008). The dimensions of career adaptability did not demonstrate a significant predictive capacity for burnout, although a negative relationship between the constructs is presented in literature (Rudolph et al., 2017).

The last model we tested intended to predict workaholism (H4). The findings indicate two IDCP-2 factors as negative predictors, Antagonism, and Routine Need. Compulsion for Work factor was the single positive predictor, indicating that individuals who have an excessive focus on work and interpersonal rigidity tend to have high workaholism levels, confirming previous evidence (Mudrack, 2004).

Our H5, predicting an increase in the explained variance when adding career adaptability resources, was partially confirmed. Specifically, the capacity to predict work engagement, job satisfaction, and burnout was increased by inserting CAAS $+\mathrm{C}$ dimensions. This finding is in line with a previous meta-analysis (Rudolph, Levigne, \& Zacher, 2017). However, our study demonstrated that career adaptability resources are good predictors of job satisfaction, distinct from the meta-analysis findings. This result may suggest that career adaptability should be evaluated in conjunction with personality traits, especially pathological traits, as explaining the variance of relevant outcomes for the worker has been 
increased with these traits in the model. On the other hand, when inserting career adaptability resources, the explained variance of workaholism decreased concerning the model only with pathological traits. This result may indicate that due to the low association between adaptability resources and the workaholism scale, when inserting these variables in the model, the regression line represents the data with highest error rate, causing the explained variance to decrease. We suggest that future studies deepen the relationship between career adaptability resources and workaholism.

Our study improves empirical findings on the selfregulatory role of career adaptability, contributing to the relationship between dispositions and behaviors (Brown \& Lent, 2016). This theoretical model has been extensively tested in literature, employing the Five-Factor model dimensions (Rudolph, Levigne, \& Zacher, 2017). However, no previous empirical reports tested the effects of career adaptability along with pathological traits. Our study showed that pathological traits are better predictors of the components of well-being at work compared to resources of career adaptability. We suggest that those interested in promoting workers' well-being evaluate and plan interventions on pathological traits and career adaptability, as these are possible predictors of well-being at work (Andreassen et al., 2016; Bianchi et al., 2018; Carvalho et al., 2019; Mróz \& Kaleta, 2016; Jackson et al., 2016; Rudolph, Levigne, \& Zacher, 2017; Rudolph et al., 2017; Wille et al., 2013; Zecca et al., 2015).

Due to the complexity of the tested model, the reduced sample of our study may have impacted the stability of the results. Therefore, we suggest new studies be conducted with larger samples. Besides, we choose factors representing pathological traits based on the empirical relationships with well-being components at work. However, this selection method restricts the number of pathological traits tested and cannot verify if other pathological traits are associated with well-being components at work. Moreover, due to several concepts and the non-agreement on which the best to explain workaholism would be, we recommend future studies to use the Intensive Longitudinal Model method. It is a model for the longitudinal study of daily measurements to assess a group of people's workaholism for a specific amount of time. This implementation seeks to verify if workaholism remains stable according to the work environment stimuli.

\section{REFERENCES}

Alessandri, G., Borgogni, L., Schaufeli, W. B., Caprara, G. V., \& Consiglio, C. (2015). From positive orientation to job performance: The role of work engagement and self-efficacy beliefs. Journal of Happiness Studies, 16(3), 767-788. https:// doi.org/10.1007/s10902-014-9543-2

Ambiel, R. A. M., Moreira, T. C., Barros, L. O., Martins, G. H., Salvador, A. P., \& Wille, B. (in press). Measuring career adaptabilities in the Brazilian context: Development and validation of the CAAS $+\mathrm{C}$ Brazilian Form. International Journal for Educational and Vocational Guidance.

Andreassen, C. S., \& Pallesen, S. (2016). Workaholism: An addiction to work. Em V. R. Preedy, Neuropathology of drug addictions and substance misuse (pp. 972-983). Academic Press.

Andreassen, C. S., Bjorvatn, B., Moen, B. E., Waage, S., Magerøy, N., \& Pallesen, S. (2016). A longitudinal study of the relationship between the five-factor model of personality and workaholism. TPM: Testing, Psychometrics, Methodology in Applied Psychology, 23(3), 285-298. https://doi.org/10.4473/ TPM23.3.2

Audibert, A., \& Teixeira, M.A. P. (2015). Escala de Adaptabilidade de Carreira: Evidências de validade em universitários brasileiros. Revista Brasileira de Orientação Profissional, 16(1), 83-93. https://www.redalyc.org/pdf/2030/203041069009.pdf

Bakker, A. B., \& Albrecht, S. (2018). Work engagement: Current trends. Career Development International, 23(1), 4-11. https:// doi.org/10.1108/CDI-11-2017-0207

Bendassolli, P. F. (2016). Mal-estar no trabalho: Do sofrimento ao poder de agir. Revista Subjetividades, 11(1), 65-99. https:// periodicos.unifor.br/rmes/article/view/4977/3985

Bianchi, R., Rolland, J. P., \& Salgado, J. F. (2018). Burnout, depression, and borderline personality: A 1,163-participant study. Frontiers in Psychology, 8, 1-10. https://doi.org/10.3389/ fpsyg.2017.02336

Bradley, D. E., \& Roberts, J. A. (2004). Self-employment and job satisfaction: Investigating the role of self-efficacy, depression, and seniority. Journal of small business management, 42(1), 37-58. https://doi.org/10.1111/j.1540-627X.2004.00096.x

Brown, S. D., \& Lent, R. W. (2016). Vocational psychology: Agency, equity, and well-being. Annual Review of Psychology, 67(27), 541-565. https://doi.org/10.1146/annurevpsych-122414-033237

Carlotto, M. S., \& Del Líbano, M. (2010). Tradução, adaptação e exploração de propriedades psicométricas da escala de adição ao trabalho "Dutch Work Addiction Scale" (DUWAS). Contextos Clínicos, 3(2), 141-150. https://doi.org/10.4013/ ctc. 2010.32 .08

Carvalho, L. D. F., \& Pianowski, G. (2015). Revision of the dependency dimension of the Dimensional Clinical Personality Inventory. Paidéia (Ribeirão Preto), 25(60), 57-65. https://doi. org/10.1590/1982-43272560201508

Carvalho, L. D. F., \& Primi, R. (no prelo). Technical manual of the Dimensional Clinical Personality Inventory 2 (IDCP-2) and Dimensional Clinical Personality Inventory screening version (IDCP-triagem). Pearson.

Carvalho, L. D. F., Souza, B. D. B. D., \& Primi, R. (2014). Psychometric properties of the revised conscientiousness dimension of Inventário Dimensional Clínico da Personalidade (IDCP). Trends in Psychiatry and Psychotherapy, 36(1), 23-31. https://doi.org/10.1590/2237-6089-2013-0024

Carvalho, L. F., Martins, G. H., Gonçalves, A. P., Sagradim, D. E. V. (2020). Personality pathology as predictor of work engagement, job satisfaction, and burnout in a community sample. Revista Psicologia Organizacional e do Trabalho, 20(1), 877-882. https://doi.org/10.17652/rpot/2020.1.16985

Clark, M. A., Michel, J. S., Zhdanova, L., Pui, S. Y., \& Baltes, B. B. (2016). All work and no play? A meta-analytic examination of the correlates and outcomes of workaholism. Journal of Management, 42(7), 1836-1873. https://doi. org/10.1177/0149206314522301

Couto, R. P., \& Paschoal, T. (2017). Relação entre ações de qualidade de vida no trabalho e bem-estar laboral. Psicologia 
Argumento, 30(70), 585-593. https://periodicos.pucpr.br/index. php/psicologiaargumento/article/view/20563/19811

Dahlin, M. E., \& Runeson, B. (2007). Burnout and psychiatric morbidity among medical students entering clinical training: A three years prospective questionnaire and interviewbased study. BMC Medical education, 7(6), 1-8. https://doi. org/10.1186/1472-6920-7-6

Evans, L. (2001). Delving deeper into morale, job satisfaction and motivation among education professionals: Re-examining the leadership dimension. Educational Management \& Administration, 29(3), 291-306. https://doi. org/10.1177/0263211X010293004

Felstead, A., Gallie, D., Green, F., \& Inanc, H. (2015). Fits, misfits and interactions: Learning at work, job satisfaction and job-related well-being. Human Resource Management Journal, 25(3), 294-310. https://doi.org/10.1111/17488583.12071

Ferreira, M. C., Valentini, F., Damásio, B. F., Mourão, L., Porto, J. B., Chinelato, R. S. D. C., ... \& Pereira, M. M. (2016). Evidências adicionais de validade da UWES-9 em amostras brasileiras. Estudos de Psicologia, 21(4), 435-445. https://doi. org/10.5935/1678-4669.20160042

Folami, B. L., Asare, K., Kwesiga, E., \& Bline, D. (2014). The impact of job satisfaction and organizational context variables on organizational commitment. International Journal of Business \& Public Administration, 11(1), 1-18. https:// digitalcommons.bryant.edu/acc_jou/64/

Gil-Monte, P. R., Carlotto, M. S., \& Câmera, S. G. (2010). Validação da versão brasileira do "Cuestionario para la Evaluación del Síndrome de Quemarse por el Trabajo" em professores. Revista de Saúde Pública, 44(1), 140-147. http://www.redalyc.org/ pdf/672/67240183015.pdf

Hakanen, J. J., Schaufeli, W. B., \& Ahola, K. (2008). The job demands-resources model: A three-year cross-lagged study of burnout, depression, commitment, and work engagement. Work \& Stress, 22(3), 224-241. https://doi. org/10.1080/02678370802379432

Hall, L. H., Johnson, J., Watt, I., Tsipa, A., \& O'Connor, D. B. (2016). Healthcare staff wellbeing, burnout, and patient safety: A systematic review. PloS one, 11(7), 1-12. https://doi. org/10.1371/journal.pone.0159015

Hu, L., \& Bentler, P. M. (1999). Cutoff criteria for fit indexes in covariance structure analysis: Conventional criteria versus new alternatives. Structural Equation Modeling: A Multidisciplinary Journal, 6(1), 1-55. https://doi. org/10.1080/10705519909540118

International Test Commission (2017). The ITC Guidelines for Translating and Adapting Testes (Second edition). https:// www.intestcom.org/files/guideline test adaptation 2ed.pdf

Jackson, S. S., Fung, M. C., Moore, M. A. C., \& Jackson, C. J. (2016). Personality and workaholism. Personality and Individual Differences, 95, 114-120. https://doi.org/10.1016/j. paid.2016.02.020

Judge, T. A., Bono, J. E., \& Locke, E. A. (2000). Personality and job satisfaction: The mediating role of job characteristics. Journal of applied psychology, 85(2), 237-249. https://doi. org/10.1037/0021-9010.85.2.237

Kim, W. G., Leong, J. K., \& Lee, Y. K. (2005). Effect of service orientation on job satisfaction, organizational commitment, and intention of leaving in a casual dining chain restaurant. International Journal of Hospitality Management, 24(2), 171193. https://doi.org/10.1016/j.ijhm.2004.05.004

Maslach, C., \& Leiter, M. P. (2016). Burnout. Em G. Fink, Stress: Concepts, cognition, emotion, and behavior (pp. 351-357). Academic Press.

Mróz, J., \& Kaleta, K. (2016). Relationships between personality, emotional labor, work engagement and job satisfaction in service professions. International journal of occupational medicine and environmental health, 29(5), 767-782. https:// doi.org/10.13075/ijomeh.1896.00578

Mudrack, P. E. (2004). Job involvement, obsessive-compulsive personality traits, and workaholic behavioral tendencies. Journal of Organizational Change Management, 17(5), 490508. https://doi.org/10.1108/09534810410554506

Mueller, C. P., \& McCloskey, J. C. (1990). Nurses' job satisfaction: A proposed measure. Nursing Research, 39, 113-117. https:// doi.org/10.1093/qjmed/hcl019

Muscatello, M. R. A., Bruno, A., Carroccio, C., Cedro, C., La Torre, D., Di Rosa, A. E., ... \& Angelone, A. M. (2006). Association between burnout and anger in oncology versus ophthalmology health care professionals. Psychological reports, 99(2), 641650. https://doi.org/10.2466/pr0.99.2.641-650

Newbury-Birch, D., \& Kamali, F. (2001). Psychological stress, anxiety, depression, job satisfaction, and personality characteristics in preregistration house officers. Postgraduate Medical Journal, 77(904), 109-111. https://doi.org/10.1136/ pmj.77.904.109

Platis, C., Reklitis, P., \& Zimeras, S. (2015). Relation between job satisfaction and job performance in healthcare services. Procedia: Social and Behavioral Sciences, 175, 480-487. https://doi.org/10.1016/j.sbspro.2015.01.1226

Rothmann, S. (2008). Job satisfaction, occupational stress, burnout and work engagement as components of work-related wellbeing. SA journal of industrial psychology, 34(3), 11-16. http://www.scielo.org.za/pdf/sajip/v34n3/02.pdf

Rudolph, C. W., Lavigne, K. N., \& Zacher, H. (2017). Career adaptability: A meta-analysis of relationships with measures of adaptivity, adapting responses, and adaptation results. Journal of Vocational Behavior, 98, 17-34. https://doi.org/10.1016/j. jvb.2016.09.002

Rudolph, C. W., Lavigne, K. N., Katz, I. M., \& Zacher, H. (2017). Linking dimensions of career adaptability to adaptation results: A meta-analysis. Journal of Vocational Behavior, 102, 151-173. https://doi.org/10.1016/j.jvb.2017.06.003

Salanova, M., Del Líbano, M., Llorens, S., \& Schaufeli, W. B. (2014). Engaged, workaholic, burned-out or just 9-to-5? Toward a typology of employee well-being. Stress and Health, 30(1), 71-81. https://doi.org/10.1002/smi.2499

Salanova, M., Llorens, S., García, M., Bürriel, R., Bresó, E., \& Schaufeli, W. B. (2005). Towards a four-dimensional model of burnout: A multigroup factor-analytic study including depersonalization and cynicism. Educational and Psychological Measurement, 65, 901-913. https://doi. org/10.1177/0013164405275662

Schaufeli, W. B. (2018). Work engagement in Europe. Organizational Dynamics, 47(2), 99-106. https://doi. org/10.1016/j.erap.2014.10.003

Schaufeli, W. B., \& Bakker, A. B. (2010). Defining and measuring work engagement: Bringing clarity to the concept. Em A. B. Bakker \& M. P. Leiter, Work engagement: a handbook of essential theory and research (pp. 10-24). Psychology Press.

Schaufeli, W. B., \& Taris, T. W. (2005). The conceptualization and measurement of burnout: Common ground and worlds apart. Work and Stress, 19, 356-362. https://doi. org/10.1080/02678370500385913

Sharma, L., Kohl, K., Morgan, T. A., \& Clark, L. A. (2013). "Impulsivity": Relations between self-report and behavior. Journal of Personality and Social Psychology, 104(3), 559575. https://doi.org/10.1037/a0031181

Shimazu, A., \& Schaufeli, W. B. (2009). Is workaholism good or bad for employee well-being? The distinctiveness of workaholism and work engagement among Japanese employees. Industrial health, 47(5), 495-502. https://doi. org/10.2486/indhealth.47.495 
Shimazu, A., Schaufeli, W. B., Kamiyama, K., \& Kawakami, N. (2015). Workaholism vs. work engagement: The two different predictors of future well-being and performance. International journal of behavioral medicine, 22(1), 18-23. https://doi. org/10.1007/s12529-014-9410-x

Siqueira, M. M. M. (2008). Satisfação no trabalho. Em M. M. M. Siqueira (Org), Medidas do comportamento organizacional: Ferramentas de diagnóstico e gestão (pp. 265-274). Artmed.

Stoeber, J., Davis, C. R., \& Townley, J. (2013). Perfectionism and workaholism in employees: The role of work motivation. Personality and Individual Differences, 55(7), 733-738. https:// doi.org/10.1016/j.paid.2013.06.001

Torp, S., Grimsmo, A., Hagen, S., Duran, A., \& Gudbergsson, S. B. (2012). Work engagement: A practical measure for workplace health promotion? Health Promotion International, 28(3), 387-396. https://doi.org/10.1093/heapro/das022
Vazquez, A. C., Freitas, C. P. P., Cyrre, A., Hutz, C. S., \& Schaufeli, W. B. (2018). Evidências de validade da versão brasileira da escala de workaholism (DUWAS-16) e sua versão breve (DUWAS-10). Avaliação Psicológica, 17(1), 69-78. https:// doi.org/10.15689/ap.2017.1701.08.13288

Wille, B., De Fruyt, F., \& De Clercq, B. (2013). Expanding and reconceptualizing aberrante personality at work: Validity of five-factor model aberrant personality tendencies to predict career outcomes. Personnel Psychology, 66(1), 173-223. https://doi.org/10.1111/Peps.12016

Zecca, G., Györkös, C., Becker, J., Massoudi, K., Bruin, G. P., \& Rossier, J. (2015). Validation of the French Utrecht Work Engagement Scale and its relationship with personality traits and impulsivity. Revue Européenne de Psychologie Appliquéel European Review of Applied Psychology, 65(1), 19-28. https:// doi.org/10.1016/j.erap.2014.10.003 